EISSN: $2706-7947 \quad$ ISSN: $2077-4613$

DOI: 10.36632/mejas/2021.11.1.5

Journal homepage: www.curresweb.com

Pages: 43-50

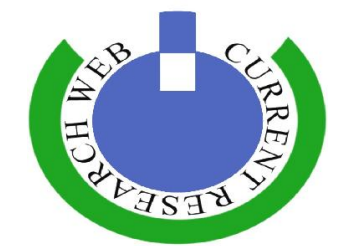

\title{
Effect of Fertigation with NPK on Growth and Yield of Seqae Date Palm Produced From Tissue Culture Grown Under Al-Wadi Al-Jadid Conditions
}

\author{
Hamdy A. Mahdy
}

Tropical Fruits Research Dept., Horticulture Research Institute, Agriculture Research Center, Giza Egypt.

Received: 15 November $2020 \quad$ Accepted: 09 January $2021 \quad$ Published: 20 January 2021

\begin{abstract}
A field study was carried out during three successive growing seasons of 2018, 2019 and 2020 on Seqae date palm produced from tissue culture grown in a private orchard at El-Dakhala Oasis, Al-Wadi AlJadid Governorate, Egypt (latitude $25^{\circ}$ and longitude $29^{\circ}$ ). The palms were received different rates of $\mathrm{N}, \mathrm{P}$ and $\mathrm{K}$ fertilization. Three $\mathrm{N}$ - fertigation rates $(\mathrm{N} 1=500, \mathrm{~N} 2=750, \mathrm{~N} 3=1000 \mathrm{~g}$ actual $\mathrm{N} / \mathrm{palm} /$ year $)$ in the form of $\mathrm{NH}_{4} \mathrm{NO}_{3}$; two P-fertigation rates $\left(\mathrm{P} 1=400\right.$ and $\mathrm{P} 2=800 \mathrm{~g}_{2} \mathrm{O}_{5} /$ palm/year $)$ as $\mathrm{H}_{3} \mathrm{PO}_{4}$ and two K-fertigation rates $\left(\mathrm{K} 1=600\right.$ and $\mathrm{K} 2=1200 \mathrm{~g} \mathrm{~K}_{2} \mathrm{O} / \mathrm{palm} /$ year) as $\mathrm{K}_{2} \mathrm{SO}_{4}$. All the considered $\mathrm{N}$ and $\mathrm{K}$ rates were divided into 80 unequal doses applied from first week of February to the last week of November ( 8 doses in each month). Full dose of nitrogen in month's (February, April, June, August and October). Half of nitrogen was used in March, May, July, August, September and November. While full dose of potassium in months (March, May, July, September and November) half of potassium was used in February, April, June, August and October. While P rate was divided into 40 doses (4 doses / month) and were added as solution by fertigation. The results showed that NP and K fertigation increased growth, fruit set, yield and improved the fruit physical characteristics (fruit weight and fruit dimension) and fruit chemical characteristics ( total sugars \% and T.S.S) at tamer stage, especially with high levels of NPK- fertigation. Thus, it is recommended to add the high levels of Nitrogen $(1000 \mathrm{~g}$ $\mathrm{N} /$ palm/year) Phosphorus $\left(800 \mathrm{~g} \mathrm{P}_{2} \mathrm{O}_{5} / \mathrm{palm}\right)$ and Potassium $\left(1200 \mathrm{~g} \mathrm{~K}_{2} \mathrm{O} /\right.$ palm /year) (treatment 12) to increase the yield and fruit quality of Seqae date palm grown under Al-Wadi Al-Jadid Governorate conditions.
\end{abstract}

Keywords: fertigation, NPK, data palm, Seqae cv.

\section{Introduction}

Date palm (Phoneix dactylifera L.) is broadly cultivated in hot arid region of the Middle East successful and extremely important subsistence crops in these regions (Marzouk, 2011). Egypt is considered the leading country among the top ten date producers. Date palm fruits are one of the most important export fruit crops in Egypt. Dialamia and \& Mohebi (2010) recommended 700g N, 500g P and $130 \mathrm{~g} \mathrm{~K} /$ tree early for the highest yield and quality of Sayer dates in Iran. Fertilization is an important and limiting factor for growth, nutritional status which increase date palm production and improves fruit quality (Soliman \&Osman, 2003; El Salhy et al., 2008). Several investigators studied the effect of nitrogen, phosphorus and potassium fertilization on fruit, yield and fruit quality of different date palm varieties. NPK are the three most needed nutrients by palms which are commonly met through fertilizers (Al-Obeed et al., 2013, 2013; El Merghany et al., 2016; Al-Qurashi et al., 2015; Elamin et al., 2017 and Salem \& Ali, 2020).

Fertilization is one of the most important cultural practices of date palm orchards to optimize both yield and fruit quality and maintain regular yearly bearing of the palms. The efficient use of water and fertilizers is a major aim in all agricultural systems (Dimes et al., 2002). Distribution of fertilizers with

Corresponding Author: Hamdy A. Mahdy, Tropical Fruits Research Dept., Horticulture Research Institute, Agriculture Research Center, Giza Egypt. 
fertigation could place the nutrients in the desired location of the root zone, reduce the fertilizers amount and increase yield compared to conventional fertilization (Solaimalai et al., 2005).

Nitrogen is a major element required by all plants and adequate nitrogen is essential for tree growth, leaf cover blossom formation and fruit set as well as fruit quality (Ahmed, 2008). Potassium is a mobile element in the plant and is an activator of enzymes that are essential for photosynthesis and respiration as well as enzymes that produce starch and proteins. It also activities enzymes involved in plant growth and improves the fruit quality (Ahmed, 2008 and Osman, 2010). A rate of nitrogen application ranging from 800 to $1100 \mathrm{~g} \mathrm{~N}$ per palm was reported by. Bamiftah (2000) recommended an amount of 2 or $3 \mathrm{~kg}$ of potassium sulphate / palm /year for high yield and fruit quality and observed that application of $800 \mathrm{~g}$ nitrogen and $375 \mathrm{~g}$ phosphorus for each tree caused the highest yield production in date palm. Abou sayed - Ahamed et al., (2005) studied the influence of N.P, and K fertilizer application on yield of Amry date palm grown in sandy soil and found that $0.40 \mathrm{~kg} \mathrm{~N} /$ tree was the best application to increasing the yield. Therefore fertilization is one of the most important practices which increase date production and improves fruit quality. Segae date palm cultivar is one of the best semi-dry dates (20$30 \%$ moisture) and it suitable for Al-Wadi Al-Jadid Governorate with high yield (Hamed et al., 2020).

The objective of the present study is determination of optimum levels of nitrogen, phosphorus and potassium in order to increasing yield and improving fruit quality date palm in cultivar Seqae produced from tissue culture and grown in Al-Wadi Al-Jadid Governorate.

\section{Materials and Methods}

\subsection{Plant Material}

This study was carried out during three successive growing seasons of 2018, 2019 and 2020 in a private orchard at El-Dakhala Oasis, Al-Wadi Al-Jadid Governorate, Egypt (latitude $25^{\circ}$ and longitude $29^{\circ}$ ) for Seqae date palm cultivar. The palms were 12 year old at the beginning of this study palms were planted at space $8 \times 8 \mathrm{~m}$ apart. Thirty six female palms were selected as uniform as possible in growth, vigor, height, pollen source and were subjected to the normal cultural practices usually carried out for date palms. The leaf/ bunch ratio was adjusted in both years, by the end of the blooming season to meet the value of $8: 1$. The palms trees were produced through the tissue culture technique. The experimental soil was classed as a clay loamy soil in texture and different in fertility according to mechanical and chemical analysis of samples according to Champan \& Pratt, (1979) Table (1). The drip irrigation with one lines per single row and promising micro -flapper emitters was used. Five drippers per palm were giving a total discharge of about 60 liters/ hour to keep pressure losses.

Table 1: Soil characteristics of date palm farm at the beginning of the experiment

\begin{tabular}{|c|c|c|c|}
\hline \multirow{2}{*}{ Properties } & \multicolumn{3}{|c|}{ Depth (cm) } \\
\hline & $0-40 \mathrm{~cm}$ & $40-80 \mathrm{~cm}$ & $80-120 \mathrm{~cm}$ \\
\hline Clay \% & 19.00 & 21.00 & 23.40 \\
\hline Silt\% & 53.00 & 46.40 & 40.00 \\
\hline Send \% & 28.00 & 32.60 & 36.6 \\
\hline Texture & Clay Loam & Clay Loam & Clay Loam \\
\hline pH & 7.97 & 8.00 & 7.91 \\
\hline EC & 0.77 & 0.84 & 0.89 \\
\hline $\mathrm{CaCo}_{3} \%$ & 1.10 & 1.30 & 1.30 \\
\hline $\mathrm{Na} \mathbf{m g} / \mathrm{L}$ & 3.11 & 2.84 & 2.24 \\
\hline K mg/L & 0.04 & 0.04 & 0.04 \\
\hline Ca mg/L & 1.92 & 1.94 & 1.99 \\
\hline $\mathrm{Cl} \mathrm{mg} / \mathrm{L}$ & 1.14 & 1.00 & 1.21 \\
\hline $\mathrm{So}_{4} \mathrm{mg} / \mathrm{L}$ & 0.97 & 0.95 & 0.94 \\
\hline
\end{tabular}

\subsection{Treatments}

Treatments were consisted of three levels of nitrogen $(\mathrm{N} 1=500, \mathrm{~N} 2=750, \mathrm{~N} 3=1000 \mathrm{~g}$. actual $\mathrm{N} /$ palm) in the form of $\mathrm{NO}_{3} \mathrm{NH}_{4}$, two levels of phosphorus $\left(\mathrm{P} 1=400\right.$ and $\mathrm{P} 2=800 \mathrm{~g} . \mathrm{P}_{2} \mathrm{O}_{5} / \mathrm{palm}$ ) in the form of $\mathrm{H}_{3} \mathrm{PO}_{4}$ and two levels of potassium $\left(\mathrm{K} 1=600\right.$ and $\mathrm{K} 2=1200 \mathrm{~g}$. actual $\left.\mathrm{K}_{2} \mathrm{O} / \mathrm{palm}\right)$ in the form of $\mathrm{K}_{2} \mathrm{SO}_{4} .50 \mathrm{~kg} / \mathrm{palm}$. Organic manure was added in December during three tested seasons. All the considered $\mathrm{N}$ and $\mathrm{K}$ rates were divided into 80 unequal doses, applied from first week February to the 
last week of November. Full dose of nitrogen in month's (February, April, June, August and October). Half of nitrogen was used in March, May, July, Sept. and Nov. While full dose of potassium in months (March, May, July, Sept. and Nov.) half of potassium was used in February, April, June, Aug and October compared to other months. While P rate was divided into 40 doses (4 doses / month) and were added as solution by fertigation. Table (2).

Table 2: Time and amount actual NPK fertigated around the year to the experimental seqae date palm.

\begin{tabular}{|c|c|c|c|c|c|c|c|c|c|c|}
\hline \multirow{2}{*}{$\begin{array}{l}\text { Treat. } \\
\text { Month }\end{array}$} & \multicolumn{3}{|c|}{ Actual N g./palm } & \multirow{2}{*}{$\begin{array}{l}\text { No. of } \\
\text { doses }\end{array}$} & \multicolumn{2}{|c|}{$\mathbf{P}_{2} \mathrm{O}_{5}$ g./palm } & \multirow{2}{*}{$\begin{array}{l}\text { No. of } \\
\text { doses }\end{array}$} & \multicolumn{2}{|c|}{$\mathrm{K}_{2} \mathrm{O}$ g./palm } & \multirow{2}{*}{$\begin{array}{l}\text { No. of } \\
\text { doses }\end{array}$} \\
\hline & 500 & 750 & 1000 & & 400 & 800 & & 600 & 1200 & \\
\hline Feb. & 66.6 & 100 & 133.3 & 8 & 40 & 80 & 4 & 40 & 80 & 8 \\
\hline Mar. & 33.33 & 50 & 66.66 & 8 & 40 & 80 & 4 & 80 & 160 & 8 \\
\hline Apr. & 66.6 & 100 & 133.3 & 8 & 40 & 80 & 4 & 40 & 80 & 8 \\
\hline May & 33.33 & 50 & 66.66 & 8 & 40 & 80 & 4 & 80 & 160 & 8 \\
\hline June & 66.6 & 100 & 133.3 & 8 & 40 & 80 & 4 & 40 & 80 & 8 \\
\hline July & 33.33 & 50 & 66.66 & 8 & 40 & 80 & 4 & 80 & 160 & 8 \\
\hline Aug. & 66.6 & 100 & 133.3 & 8 & 40 & 80 & 4 & 40 & 80 & 8 \\
\hline Sept. & 33.33 & 50 & 66.66 & 8 & 40 & 80 & 4 & 80 & 160 & 8 \\
\hline Oct. & 66.6 & 100 & 133.3 & 8 & 40 & 80 & 4 & 40 & 80 & 8 \\
\hline Nov. & 33.33 & 50 & 66.66 & 8 & 40 & 80 & 4 & 80 & 160 & 8 \\
\hline Total & 500 & 750 & 1000 & 80 & 400 & 800 & 40 & 600 & 1200 & 80 \\
\hline
\end{tabular}

Treatments were

$\begin{array}{llllllll}\mathbf{T}_{1} & \text { N1P1K1 } & \mathbf{T}_{4} & \text { N1P2K } & \mathbf{T}_{\mathbf{8}} & \text { N2P2K2 } & \text { T10 }_{10} & \text { N3P1K2 } \\ \mathbf{T}_{\mathbf{2}} & \text { N1P1K2 } & \mathbf{T}_{\mathbf{5}} & \text { N2P1K1 } & \mathbf{T}_{7} & \text { N2P2K1 } & \text { T11 }_{11} & \text { N3P2K1 } \\ \mathbf{T}_{3} & \text { N1P2K1 } & \mathbf{T}_{\mathbf{6}} & \text { N2P1K2 } & \mathbf{T}_{9} & \text { N3P1K1 } & \text { T12 } & \text { N3P2K2 }\end{array}$

The following parameters were used to evaluate the tested treatments:

\subsection{Growth parameters}

1. Palm height and trunk perimeter, and number of leaves /palm /year were measured and recorded in the end of each tested seasons.

2. Fruit set percentage

The number of nods and set fruits in twenty-five strands per palm were recorded after 4 weeks of pollination. The percentage of fruit set was calculated using the following formula

$$
\text { Fruit set } \%=\frac{\text { Total number of set fruit/stand }}{\text { Total number of nods } / \text { stand }} \times 100
$$

\subsection{Yield/ palm and fruit quality.}

At time of harvesting (September) number of bunch per palm and weight of all bunch were counted and recorded sample of 50 full mature fruits were randomly selected from each palm for determining fruit weight $(\mathrm{g})$ fruit length $(\mathrm{cm})$ fruit diameter $(\mathrm{cm})$, total soluble solids (TSS) was determined by hand refractometer ,total acidity was determined as g citric acid/ $100 \mathrm{~g}$ juice and total soluble sugars was determined according to the methods of A.O.A.C. (2005).

\subsection{Statistical analysis}

The experiment was conducted as a randomized complete design with three replicates (one palm/ replicate) for each treatment ( 3 replicates X 3 N levels $X_{2} \mathrm{P}_{2} \mathrm{O}_{5}$ levels X $2 \mathrm{~K}_{2} \mathrm{O}$ levels ). Statistical analysis was carried out according to Snedecor and Cochran (1989). Mean separation was came out using the method of New least significant differences (New L.S.D) described by Waller \&Duncan,(1969). 


\section{Results and Discussion}

\subsection{Growth parameters}

Data in Table (3) show that growth parameters (palm height, trunk perimeter and number of leaves /palm) of the Seqae date palm produced from tissue culture under Al -Wadi Al-Jadid Governorate during three tested seasons significantly varied due $\mathrm{N}$-fertigation rates $(500,750$ or $1000 \mathrm{~g}$. N/palm /year) P-fertigation rates 400 g. $\mathrm{P}_{2} \mathrm{O}_{5}$ or 800 g. $\mathrm{P}_{2} \mathrm{O}_{5} /$ palm / year and K- fertigation rates $(600$ or 1200 g. K2O/ palm /year). Growth parameters were significantly increased by increasing NPK-fertigation rate. Treatment 12 consisting of using $1000 \mathrm{~g}$. N: 800 g. $\mathrm{P}_{2} \mathrm{O}_{5}$ and $1200 \mathrm{~g} \mathrm{~K}_{2} \mathrm{O} / \mathrm{palm} /$ year caused the highest growth parameters (plant high. Trunk perimeter and number of leaves $/$ palm) $(3.34: 3.40: 3.75 \mathrm{~m})$; (2.75: 3.15: $3.60 \mathrm{~m})$ and $(107: 118: 130$ leaf) during three seasons respectively. The lowest value of growth parameters was found in $\mathrm{T} 1\left(500 \mathrm{~g}\right.$. $\mathrm{N}+400 \mathrm{~g} . \mathrm{P}_{2} \mathrm{O}_{5}+600$ g. $\mathrm{K}_{2} \mathrm{O} /$ palm/year) $(2.5,2.85,3.07 \mathrm{~m}$, $2.40,2.71,3.01 \mathrm{~m} .82,92,100$ leaf) plant height, trunk parameters and number of leaves/ palm during three seasons respectively. These results are in agreement with those obtained by Shahin 2007, Al_Qurashi et al., 3015 ;Ibrahim et al., 2013: Zean El -Daen,2019.

Table 3: Effect of N, P and $\mathrm{K}$. fertigation on growth parameters of Seqae date palm produced from tissue culture under Al-Wadi Al- Jadid Governorate during 2018, 2019 and 2020 seasons.

\begin{tabular}{|c|c|c|c|c|c|c|c|c|c|c|c|c|}
\hline \multicolumn{4}{|c|}{ Treatments } & \multirow{2}{*}{\multicolumn{3}{|c|}{$\begin{array}{l}\text { Palm height } \\
\text { (m) }\end{array}$}} & \multirow{2}{*}{\multicolumn{3}{|c|}{$\begin{array}{l}\text { Trunk perimeters } \\
\text { (m) }\end{array}$}} & \multirow{2}{*}{\multicolumn{3}{|c|}{$\begin{array}{l}\text { No. of leaves } \\
\text { / palm }\end{array}$}} \\
\hline \multirow[t]{2}{*}{ No. } & \multicolumn{3}{|c|}{$\begin{array}{c}\text { Fertigation } \\
\text { (g/palm/year) }\end{array}$} & & & & & & & & & \\
\hline & $\mathbf{N}$ & $\mathbf{P}_{2} \mathbf{O}_{5}$ & $\mathbf{K}_{2} \mathbf{O}$ & 2018 & 2019 & 2020 & 2018 & 2019 & 2020 & 2018 & 2019 & 2020 \\
\hline 1 & 500 & 400 & 600 & 2.50 & 2.85 & 3.07 & 2.40 & 2.71 & 3.01 & 82 & 92 & 100 \\
\hline 2 & 500 & 400 & 1200 & 2.69 & 2.96 & 3.26 & 2.65 & 3.01 & 3.11 & 81 & 92 & 102 \\
\hline 3 & 500 & 800 & 600 & 2.71 & 3.00 & 3.20 & 2.61 & 3.04 & 3.21 & 94 & 102 & 109 \\
\hline 4 & 500 & 800 & 1200 & 3.0 & 3.23 & 3.41 & 2.70 & 3.00 & 3.17 & 96 & 105 & 113 \\
\hline 5 & 750 & 400 & 600 & 2.80 & 3.0 & 3.31 & 2.70 & 3.02 & 3.30 & 90 & 97 & 116 \\
\hline 6 & 750 & 400 & 1200 & 2.94 & 3.15 & 3.35 & 2.75 & 3.05 & 3.25 & 93 & 103 & 117 \\
\hline 7 & 750 & 800 & 600 & 2.74 & 3.00 & 3.31 & 2.60 & 3.01 & 3.22 & 96 & 106 & 118 \\
\hline 8 & 750 & 800 & 1200 & 3.10 & 3.30 & 3.61 & 2.70 & 3.10 & 3.39 & 99 & 108 & 119 \\
\hline 9 & 1000 & 400 & 600 & 3.04 & 3.20 & 3.60 & 2.75 & 3.05 & 3.32 & 98 & 108 & 122 \\
\hline 10 & 1000 & 400 & 1200 & 2.85 & 3.10 & 3.60 & 2.65 & 3.05 & 3.37 & 99 & 110 & 125 \\
\hline 11 & 1000 & 800 & 600 & 3.12 & 3.25 & 3.71 & 2.71 & 3.02 & 3.50 & 104 & 116 & 128 \\
\hline 12 & 1000 & 800 & 1200 & 3.34 & 3.40 & 3.75 & 2.75 & 3.15 & 3.60 & 107 & 118 & 130 \\
\hline Nev & S.D a & .05 & & 0.15 & 0.17 & 0.14 & 0.11 & 0.123 & 0.10 & 0.362 & 0.391 & 0.431 \\
\hline
\end{tabular}

The obtained results as presented in Tables (3) showed that application of N,P and $\mathrm{K}$ fertigation caused significant increase in growth parameters These improvements might be interpreted by efficient uptake and metabolism of N, P and K under the conditions of the study, therefore increase in nutrients uptake enhanced fruit trails. However, the physical characteristics of fruit are expression of the plant's vegetative activity, so, it may be presumed that the $\mathrm{N}, \mathrm{P}$ and $\mathrm{K}$ treatments at optimum level lead to increase in shoot and leaf development that is ultimately capable of manufacturing greater amount of food materials and when translocated to the fruit bearing areas lead to enhancement in length and width of the fruits.

\subsection{Fruit set}

Fruit set percentage was ranged between $70,73,71 \%$ in treatment $1(500$ g. $\mathrm{N}+400 \mathrm{~g}$. $\mathrm{P}_{2} \mathrm{O}_{5}+600$ g. K2O) and $91,91 \& 90 \%$ in treatment $12\left(1000\right.$ g. N+ 800 g. $\mathrm{P}_{2} \mathrm{O}_{5}+1200$ g. K2O) in three tested seasons (Table, 4).

\subsection{Yield}

The present results indicated that fertigation treatments caused a significant increase in yield $(\mathrm{kg}$. /Palm). Treatment 12 (1000 g. N, 800 g. $\mathrm{P}_{2} \mathrm{O}_{5}$ and 1200 g. K2O for each palm) caused the highest yield $(128,124,132 \mathrm{~kg} . / \mathrm{palm})$ while the lightest bunches were obtained from the plants received the low amount of $\mathrm{N}, \mathrm{P}$ and $\mathrm{K}$ fertigation in treatment 1 (500 g. $\mathrm{N}+400$ g. $\mathrm{P}_{2} \mathrm{O}_{5}$ and 600 g. $\mathrm{K}_{2} \mathrm{O}(90,94,102$ $\mathrm{kg} / \mathrm{palm}$ ) in the three tested seasons ( Table 3). The present results may be attributed to the physical 
role of potassium in enhancing many metabolic processes such as carbohydrate formation, translocation and accumulation Marschner, 1986. Archer (1985) reported that translocation of photosynthetic depended on cell potassium concentration. In addition to nitrogen, phosphorus is necessary for protein synthesis and energy carriers like ATP (Mengel \& Kirkby, 1978), so, using these essential elements could increase the yield. Results of the effect of different NPK rates on yield of date palm were in harmony with the findings of Dialami \& Pezhman., 2005; Fahim \& Saleh (2007); Osman, (2010); Kassem, (2012); El-Merghany et al., (2014); Khan et al., (2016) and Elamin et al., (2017). Yield increase with using nitrogen and phosphorus fertilizers in date Palm was reported by Soliman \& Osman, 2003; Osman, 2010; Ezz et al. 2010, Al- Obeed et al., (2013) Al - Qurashi (2015); Khan et al., (2016)

\subsection{Fruit quality as physical characteristics.}

Some physical characteristics of fruit such as fruit weight, fruit length and diameter significantly varied in response to $\mathrm{N}, \mathrm{P}$ and $\mathrm{K}$ fertigation treatments. Date in Tables $(4 \& 5)$ show that fruit weight tended to increase by increasing rate of NPK - fertigation.

Table 4: Effect of N, P and K. fertigation on yield and fruit weight of Seqae date palm produced from tissue culture under Al- Wadi Al Jadid Governorate during 2018, 2019 and 2020 seasons

\begin{tabular}{|c|c|c|c|c|c|c|c|c|c|c|c|c|}
\hline \multicolumn{4}{|c|}{ Treatments } & \multicolumn{3}{|c|}{ Fruit set \% } & \multicolumn{3}{|c|}{ Yield (kg./palm ) } & \multicolumn{3}{|c|}{ Fruit Weight (gm) } \\
\hline \multirow{2}{*}{ No. } & \multicolumn{3}{|c|}{$\begin{array}{l}\text { Fertigation } \\
\text { (g/palm/year) }\end{array}$} & \multirow[t]{2}{*}{2018} & \multirow[t]{2}{*}{2019} & \multirow[t]{2}{*}{2020} & \multirow[t]{2}{*}{2018} & \multirow[t]{2}{*}{2019} & \multirow[t]{2}{*}{2020} & \multirow[t]{2}{*}{2018} & \multirow[t]{2}{*}{2019} & \multirow[t]{2}{*}{2020} \\
\hline & $\mathbf{N}$ & $\mathbf{P}_{2} \mathbf{O}_{5}$ & $\mathbf{K}_{2} \mathbf{O}$ & & & & & & & & & \\
\hline 1 & 500 & 400 & 600 & 70 & 73 & 71 & 90 & 94 & 102 & 17.2 & 20.1 & 21.0 \\
\hline 2 & 500 & 400 & 1200 & 74 & 77 & 79 & 94 & 98 & 107 & 18.3 & 22.3 & 23.2 \\
\hline 3 & 500 & 800 & 600 & 77 & 79 & 79 & 95 & 98 & 108 & 19.3 & 23.0 & 22.7 \\
\hline 4 & 500 & 800 & 1200 & 79 & 78 & 79 & 99 & 103 & 109 & 20.1 & 24.2 & 24.0 \\
\hline 5 & 750 & 400 & 600 & 81 & 80 & 81 & 96 & 104 & 111 & 22.0 & 24.7 & 24.1 \\
\hline 6 & 750 & 400 & 1200 & 83 & 84 & 82 & 100 & 108 & 118 & 23.0 & 25.0 & 26.1 \\
\hline 7 & 750 & 800 & 600 & 83 & 85 & 85 & 100 & 110 & 120 & 21.0 & 24.2 & 25.0 \\
\hline 8 & 750 & 800 & 1200 & 86 & 87 & 86 & 106 & 114 & 121 & 24.0 & 26.1 & 26.8 \\
\hline 9 & 1000 & 400 & 600 & 89 & 86 & 87 & 103 & 108 & 117 & 21.0 & 23.4 & 24.0 \\
\hline 10 & 1000 & 400 & 1200 & 89 & 87 & 85 & 110 & 116 & 122 & 24.0 & 25.6 & 26.1 \\
\hline 11 & 1000 & 800 & 600 & 90 & 88 & 87 & 108 & 112 & 118 & 23.0 & 24.0 & 24.2 \\
\hline 12 & 1000 & 800 & 1200 & 91 & 91 & 90 & 118 & 124 & 132 & 24.8 & 27.2 & 28.0 \\
\hline \multicolumn{4}{|c|}{ New L.S.D at 0.05} & 2.88 & 3.04 & 2.94 & 3.02 & 3.09 & 3.12 & 0.41 & 0.37 & 0.22 \\
\hline
\end{tabular}

Table 5: Effect of N, P and K. fertigation on fruit length and diameters of Seqae date palm produced from tissue culture under Al-Wadi Al Jadid Governorate during 2018, 2019 and 2020 seasons.

\begin{tabular}{|c|c|c|c|c|c|c|c|c|c|}
\hline \multicolumn{4}{|c|}{ Treatments } & \multicolumn{3}{|c|}{ Fruit length (cm) } & \multicolumn{3}{|c|}{ Fruit diameters(cm) } \\
\hline No. & $\underset{\mathbf{N}}{\text { Fertiga }}$ & $\begin{array}{l}(\mathbf{g} / \mathbf{p a l} \\
\mathbf{P}_{2} \mathbf{O}_{5}\end{array}$ & $\begin{array}{l}\text { ear) } \\
\mathbf{K}_{2} \mathbf{O}\end{array}$ & 2018 & 2019 & 2020 & 2018 & 2019 & 2020 \\
\hline 1 & 500 & 400 & 600 & 4.10 & 4.17 & 4.15 & 2.44 & 2.34 & 2.39 \\
\hline 2 & 500 & 400 & 1200 & 4.20 & 4.31 & 4.20 & 2.50 & 2.37 & 2.42 \\
\hline 3 & 500 & 800 & 600 & 4.42 & 4.44 & 4.31 & 2.55 & 2.42 & 2.42 \\
\hline 4 & 500 & 800 & 1200 & 4.50 & 4.61 & 4.34 & 2.62 & 2.48 & 2.74 \\
\hline 5 & 750 & 400 & 600 & 4.57 & 4.55 & 4.50 & 2.64 & 2.49 & 2.49 \\
\hline 6 & 750 & 400 & 1200 & 4.53 & 4.62 & 4.54 & 2.67 & 2.51 & 2.50 \\
\hline 7 & 750 & 800 & 600 & 4.61 & 4.66 & 4.60 & 2.60 & 2.51 & 2.52 \\
\hline 8 & 750 & 800 & 1200 & 4.70 & 4.70 & 4.68 & 2.69 & 2.55 & 2.54 \\
\hline 9 & 1000 & 400 & 600 & 4.30 & 4.30 & 4.40 & 2.54 & 2.50 & 2.52 \\
\hline 10 & 1000 & 400 & 1200 & 4.70 & 4.74 & 4.74 & 2.65 & 2.57 & 2.55 \\
\hline 11 & 1000 & 800 & 600 & 4.50 & 4.60 & 4.53 & 2.65 & 2.42 & 2.40 \\
\hline 12 & 1000 & 800 & 1200 & 4.75 & 4.76 & 4.74 & 2.72 & 2.61 & 2.57 \\
\hline \multicolumn{4}{|c|}{ New L.S.D at 0.05} & 036 & 0.32 & 0.38 & 0.05 & 0.042 & 0.049 \\
\hline
\end{tabular}

As such, the uppermost rate $1000 \mathrm{~g} \mathrm{~N} ., 800 \mathrm{~g} \mathrm{P}_{2} \mathrm{O}_{5}, 1200 \mathrm{~g} \mathrm{~K} 2 \mathrm{O} / \mathrm{palm} /$ year gave the highest values in fruit weight $(24.8,27.2,28.0)$ and fruit length $(4.75,4.76,4.74)$ and diameter $(2.5,2.73,3.39)$ in the three seasons respectively, as compared with treatment 500g N+400g $\mathrm{P}_{2} \mathrm{O}_{5}+600 \mathrm{~g} \mathrm{~K} 2 \mathrm{O} / \mathrm{palm}(17.2$ 
,20.1,21.0g)(4.10,4.17,4.15cm) $(2.44,2.34,2.39 \mathrm{~cm})$ in the three tested seasons, respectively. In this respect, the remainder treatment $\mathrm{T} 3, \mathrm{~T} 5, \mathrm{~T} 6, \mathrm{~T} 7, \mathrm{~T} 8, \mathrm{~T} 9, \mathrm{~T} 10, \mathrm{~T} 11$ had an intermediate value of fruit weight and fruit diameter. These results are in agreement with those obtained by Kein\& Zaid, (2005); Fahim \& Saleh, (2007); Zean El-Daen, (2019).

\subsection{Fruit quality as chemical characteristics}

Some chemical characteristics of fruit such as total sugars $\%$ and T.S.S $\%$ of fruit were significant affected by NPK fertigation treatments. As such,T8( $\left.750 \mathrm{~g} \mathrm{~N}+800 \mathrm{~g} \mathrm{P}_{2} \mathrm{O}_{5}+1200 \mathrm{~g} \mathrm{K2O}\right)$ increased total sugars of fruit $(78.9,79.0,78.6)$ and T.S.S\% $(74,71,71)$ in the three tested seasons respectively. Application of different levels of NPK fertigation enhanced total sugars and T.S.S\% in date fruit (Table 6). The total sugars\% of Seqae date fruit increased significantly by the application of PK- fertilization treatments. These results are due to the fact that potassium activities the enzymes involved in sugar biosynthesis and helps in translocation of sugars (Archer, 1985). The obtained results appear to be in close agreement with the finding reported by El-Deeb et al., 2000 on date palm. Fruit acidity\% was not significant affected by NPK fertigation. The depicted data in Table 6 indicated that all tested fertigation treatments increased fruit total solids (TSS) during the three seasons of the study compared with the treatment $1\left(500 \mathrm{~h} \mathrm{~N}+400 \mathrm{~g} \mathrm{P}_{2} \mathrm{O}_{5}+600 \mathrm{~g} \mathrm{~K} 2 \mathrm{O} /\right.$ palm /year).Al- Juburi et al.,1991 found that nitrogen application at $600 \mathrm{~g} / \mathrm{palm}$ annually increased fruit yield/palm. Soliman \& Osman (2003) who found that the yield was significantly increased by nitrogen and potassium fertilization. The results are in harmony with Ibrahim et al., (2013) who found that N, P and K produced the highest fruit yield per palm on Sewy date palm. The same trend was observed by Al- Qurashi (2015) who found that the highest fertilization regime applied either as soil broadcast or as fertigation produced the highest total yield per palm of Barhee date palm. Fatima \& Dawoud (2016) investigated the effect of $1000 \mathrm{~g}$ total $\mathrm{N}$ per palm and found that fruit yield of Barhee date palm was increased.

Table 6: Effect of N, P and K. fertigation on some chemical properties of fruit of Seqae date palm produced from tissue culture under Al- Wadi Al Jadid Governorate during 2018, 2019 and 2020 seasons.

\begin{tabular}{|c|c|c|c|c|c|c|c|c|c|c|c|c|}
\hline \multicolumn{4}{|c|}{ Treatments } & \multirow{2}{*}{\multicolumn{3}{|c|}{$\begin{array}{l}\text { T.S.S } \\
(\%)\end{array}$}} & \multirow{2}{*}{\multicolumn{3}{|c|}{$\begin{array}{l}\text { Total sugars of fruit } \\
\text { (\%) }\end{array}$}} & \multirow{2}{*}{\multicolumn{3}{|c|}{$\begin{array}{l}\text { Fruit acidity } \\
\text { (\%) }\end{array}$}} \\
\hline \multirow{2}{*}{ No. } & \multicolumn{3}{|c|}{$\begin{array}{c}\text { Fertigation } \\
\text { (g/palm/year) }\end{array}$} & & & & & & & & & \\
\hline & $\mathbf{N}$ & $\mathbf{P}_{2} \mathrm{O}_{5}$ & $\mathrm{~K}_{2} \mathrm{O}$ & 2018 & 2019 & 2020 & 2018 & 2019 & 2020 & 2018 & 2019 & 2020 \\
\hline 1 & 500 & 400 & 600 & 72.4 & 74.0 & 73.0 & 66.0 & 64.0 & 71.0 & 0.18 & 0.20 & 0.17 \\
\hline 2 & 500 & 400 & 1200 & 74.1 & 77.3 & 74.0 & 69.0 & 67.0 & 73.0 & 0.18 & 0.21 & 0.16 \\
\hline 3 & 500 & 800 & 600 & 73.3 & 73.0 & 73.4 & 70.0 & 70.0 & 66.0 & 0.17 & 0.12 & 0.16 \\
\hline 4 & 500 & 800 & 1200 & 75.0 & 77.4 & 76.0 & 72.0 & 70.0 & 71.0 & 0.18 & 0.20 & 0.17 \\
\hline 5 & $\mathbf{7 5 0}$ & 400 & 600 & 74.0 & 76.1 & 75.0 & 63.0 & 62.0 & 68.0 & 0.17 & 0.21 & 0.16 \\
\hline 6 & 750 & 400 & 1200 & 76.0 & 78.0 & 78.0 & 68.0 & 66.0 & 70.0 & 0.17 & 0.20 & 0.15 \\
\hline 7 & $\mathbf{7 5 0}$ & 800 & 600 & 75.0 & 74.0 & 74.0 & 70.0 & 69.0 & 68.0 & 0.18 & 0.21 & 0.16 \\
\hline 8 & $\mathbf{7 5 0}$ & 800 & 1200 & 78.9 & 79.0 & 78.6 & 74.0 & 71.0 & 71.0 & 0.17 & 0.22 & 0.17 \\
\hline 9 & 1000 & 400 & 600 & 74.0 & 73.0 & 73.0 & 64.0 & 62.0 & 65.0 & 0.18 & 0.21 & 0.17 \\
\hline 10 & 1000 & 400 & 1200 & 75.1 & 75.0 & 74.1 & 70.0 & 68.0 & 70.0 & 0.17 & 0.20 & 0.16 \\
\hline 11 & 1000 & 800 & 600 & 73.0 & 74.0 & 74.2 & 68.0 & 67.0 & 65.0 & 0.18 & 0.21 & 0.17 \\
\hline 12 & 1000 & 800 & 1200 & 77.0 & 76.0 & 75.0 & 70.0 & 69.0 & 70.0 & 0.18 & 0.21 & 0.16 \\
\hline & & & & 44 & 0.49 & 0.52 & 2.0 & 2.10 & 2.24 & N.S & N.S & N.S \\
\hline
\end{tabular}

\section{References}

Abassi, M. K., M. Kasmi, and F. Hussan, 2005. Nitrogen use efficiency and herbage production of an established grass sward in relation to moisture and nitrogen fertilization. J. Plant Nutr., 28: 16931708.

Abou Sayed-Ahmed, T.A., K.M. Abdalla, F.B. EL-Makhtoum, and M.A. Aly, 2005. Influence of some fertilization treatments on yield and fruit quality of Amry date palms grown in sandy soil. Zagazig J. Agric. Res., (32): 1475-1499.

Ahmed, E.F.S., 2008. Physiological studies on the behavior of Saidy date palms under some treatments.' Ph.D. Thesis, Fac. Agric., Assiut Univ., Egypt. 
Al-Obeed, R.S., H.A. Kassem, and M.A. Ahmed, 2013. Effect of levels and methods of potassium and phosphorus fertilization on yield, fruit quality and chemical composition of "Khalas" date palm cultivar, Life Science Journal, 10(4): 1111-1118.

Al-Qurashi, A.D., A.A. Mohamed, and M.M.S. Saleh, 2015. Growth, yield, fruit quality and nutrient uptake of tissue culture-regenerated 'Barhee' date palms grown in a newly established orchard as affected by NPK fertigation. Scientia Horticulturae, 184: 114-122.

Archer, J., 1985. Crop nutrition and fertilizer use. Farming Press, Ipswich. Ltd 285.

A.O.A.C., 2005. Association of Official Analytical Chemists, Official Methods of Analysis, 26th edition. Washington D.C., USA.

Awad, M.A., O.H. Eshkandi, and M.A. Badawi, 2006. Effect of elemental sulfur, chemical and organic fertilizers on nutrient uptake, yield and fruit quality of date palm trees. In: 7th Annual U.A.E. University Research Conference, 34-39.

Bamiftah, M.A.O., 2000. Effect of potassium fertilization and bunch thinning on yield and fruit quality of 'Zaghloul' date palm. M.Sc. Thesis, Fac. Agric. Sci., Saba Basha, Alex. Univ.

Chapman, H.D. and P.F. Pratt, 1979. Métodos de análisis para suelos, plantas y agua. Trillas, México, D.F.

Dimes, J., S. Twomlow, and P. Carberry, 2002. Application of APSIM in smallholder farming systems in the semiarid tropics. In: Bontkes TS, Wopereis MCS (eds) A practical guide to decisionsupport tools for smallholder agriculture in sub-Saharan Africa. International Center for Soil Fertility and Agricultural Development (IFDC). Africa Division BP 4483, Lome' Togo, 85-9.

Dialami, H. and H. Pezhman, 2005. The Effect of Foliar Application of Potassium Sulfate, Potassium Nitrate and Manganese Sulfate on Yield and Quantity Characteristics of Cultivar Touri of Date Palm. 1st International Festival and Symposium on Date Palm. Bandar Abbas, Iran. 20-21 Nov.

Dialami, H. and A.H. Mohebi, 2010. Increasing yield and fruit quality of date palm 'Sayer' with application of nitrogen, phosphorus and potassium. Acta Hort., 882: 353-360

El-Deeb, M.A., H.H. Sharara, and M.N. Makled, 2000. Enhanced calcium and phosphorus utilization by enzyme phytase supplemented to broiler diet containing rice bran. Egyptian Poult. Sci. J., 20 (3): 545-566.

Elamin, A.H., E.H. Elsadig, H.J. Aljubouri and M.O. GAfer, 2017. Improving fruit quality and yield of Khenazi date palm( Phoenix dactilifera L.) grown in sandy soil by application of nitrogen, phosphorus, potassium and organic manure, International J. of Development and Sustainability, 6(8): 862-875.

El-Salhy, A.M., H.A. Abdel-Galil, M.M. El-Akkad, and Y.M. Diab, 2008. Effect of mineral and organic nitrogen fertilization on vegetative growth, yield and fruit characteristics of Sewy date palms', $3^{\text {rd }}$ Inter. Conf. for Date palms Agric. Sci. and Environ. Fac. Suez Canal University.

El-Salhy M., T. Solomon, T. Hausken, O.H. Gilja and J.G. Hatlebakk, 2017. Gastrointestinal neuroendocrine peptides/amines in inflammatory bowel disease World J. Gasoenterol., 23: 50685086.

Ezz T.M., H.A. Kassem and H.A. Marzouk, 2010. Response of date palm trees to different nitrogen and potassium application rates. Acta Hortic., 882.84.

Fahim, M. and J. Saleh, 2007. Effects of nitrogen, phosphorus and potassium fertilizers on yield and fruit quality of date palm'. The Fourth Symposium on date palm in Saudi Arabia, Date Palm Research Center; King Faisal University -Al Hassa Al Hassa, 5-8 May.

Fatima, A.A. and H.D. Dawoud, 2016. Effect of different nitrogen sources on Barhi date palm growing under heavy alkaline soil. 2nd International Conference for date palm in Qassim, Kingdom of Saudi Arabia, from 10-12 October, 49-60.

Hamed A.M., Y.M.S. Diab, H.A. Mahdy and N.M. Abd El-Gawad, 2020. Economic and numerical evaluation of some date palm cultivars grown in Al-wadi Al-Jadid governorate. Journal of Horticultural Science \& Ornamental Plants, 12 (2): 136-142.

Harhash, M.M. and G. Abdel-Nasser, 2010. Improving of fruit set, yield and fruit quality of "khalas" tissue culture derived date palm through bunches spraying with potassium and/or boron", Australian Journal of Basic and Applied Sciences, 4 (9): 4164-4172.

Ibrahim, M.M., R.T. El-Beshbeshy, A.R. Kamh, and A.I. Abour-Amer, 2013. Effect of NPK and biofertilizer on date palm trees grown in Siwa Oasis, Egypt. Soil, 29(3): 315-321. 
Kassem, H.A., 2012. The response of date palm to calcareous soil fertilization.' J. Soil Sci. Plant Nutr., 12 (1): 45-58.

Klein, P. and A. Zaid, 2000. Date palm fertilization: Updated information for modern date cultivation in Namibia. Proceeding of Date Palm International Symposium, Windhoek, Namibia.

Khan, A., X.Q. Zhao, M.T. Javed, K.S. Khan, A. Bano, R.F. Shen, et al., 2016. Bacillus pumilus enhances tolerance in rice (Oryza sativa $\mathrm{L}$.) to combined stresses of $\mathrm{NaCl}$ and high boron due to limited uptake of $\mathrm{Na}+$. Environ. Exp. Bot. 124: 120-129.

Marschner, H., 1986. Mineral nutrition of higher plants. Academic Press: Harcourt Brace Jovannovich, Publishers. London, San Diego, New York and Tokyo, 673.

Marzouk, H.A., 2011. Soil Fertilization study on Zaghloul date palm grown in calcareous Soil and Irrigated with drainage water, American-Eurasian J. Agric. \& Environ. Sci., 10 (5): 728-736.

Mengel, K. and E.A. Kirkby, 1978. Principles of plant nutrition. International Potash Institute, Worbhavefen-Bern, Switzerland. 375.

Merghany, S., I.E., Abd El-Rahman and E.M.A., Zaen El - Dean, 2016. Influence of potassium fertilization on Barhee date palms growth, yield and fruit quality under heat stress conditions. Journal of plant production, 9 (1):73-80.

Osman, S.M., 2010. Effect of potassium fertilization on yield, leaf mineral content and fruit quality of Bartamoda date palm propagated by tissue culture technique under Aswan conditions', J. Applied Sci. Res., 6(2):184-190.

Saleh, J., 2009. Yield and chemical composition of 'Piarom' date palm Phoenix dactylifera as affected by nitrogen and phosphorus levels. Int. J. Plant Production (IJPP) 2(3):57-64.

Salem, E.H. and H.A.M. Ali., 2020. Effect of slow release fertilizers on growth and fruiting of Khalas date palm. International Journal of Agricultural Sciences, 2(2): 30-44.

Snedecor, G.W. and G.W. Cochran, 1989. Statistical Methods, 8th edition. Iowa State University Press, Iowa, USA.

Solaimalai, A., M. Baskar, A. Sadasakthf, A. Solaimalai, M. Baskar, A. Sadasakthi, and K. Subburamu, 2005. Fertigation in high value crops. Agriculture Reviews, 26(1): 1-13.

Soliman, S.S. and S.M., Osman, 2003. Effect of nitrogen and potassium fertilization on yield, fruit quality and some nutrients content of Samany date palm. Ann Agric Sci., Cairo 48, 283-296.

Waller, R.A. and D.B. Duncan, 1969. A bays rule for the symmetric multiple comparison proplems. Amer. State. Assoc. J., 64:1484-1503.

Zaen El-Daen, E.M.A., 2019. Effect of fertilization by injection of soil and trunk with NPK on productivity and fruits quality of Sewy 9th International Conference for Sustainable Agricultural Development 4-6 March Fayoum J. Agric. Res. \& Dev., 33 1(B) March.146-160. 